\title{
Social Capital Influence Towards Sustainability of Herbal Medicine Trade In Nguter Market Sukoharjo
}

\author{
Fitria Rismaningtyas \\ Graduate Student of Universitas Sebelas Maret \\ Surakarta, Indonesia. \\ Yulius Slamet \\ Postgraduate Department of Sociology, Universitas Sebelas Maret \\ Surakarta, Indonesia. \\ Bagus Haryono \\ Postgraduate Department of Sociology, Universitas Sebelas Maret \\ Surakarta, Indonesia.
}

\begin{abstract}
The aim of this research is to analyze total direct influence of trust and networks towards sustainability of herbal medicine trade in Nguter market Sukoharjo. This research begun at February, 2018. Data collection through observation and questionnaire towards herbal medicine trader in Nguter market. The data analysis done by description and path analysis. The data processing using SPSS 21 Software as analysis tool. The result show that there's direct influence of trust variable towards the sustainbility of herbal medicine trade, 0.378 or $14.2 \%$. Meanwhile direct influence of networks variable towards the sustainbility of herbal medicine trade, 0.374 or $12.1 \%$. Trust variable has bigger contribution than network variable, $14.2 \%>12.1 \%$. This number shows the importance of trust among herbal medicine traders, market administrator, herbal medicine's fund managment agency, and the herbal medicine customers. Trust variable has big role on sustainbility of herbal medicine trade, there's desire and needs to maintain the trust among the related actors.
\end{abstract}

Keywords: social capital, networks, trust, sustainbility trade, herbal medicine traders.

\section{INTRODUCTION}

Health is one of Indonesian development program. The aim of health development is to have optimum health rate of society. One of the effort to support it is through herbal medicine. Herbal medicine extensively used by society years ago in the past until this present time, and herbal medicine tend to show a increasing progress (Hargono, 1992) in (Arifin, 2010). Herbal medicine become part of culture and natural resourses treasure of Indonesia and the report of Basic Health Research in 2010 shows that herbal consumption by society is more than $50 \%$ (Purwaningsih, 2013).

Traditional herbal medicine is well known form the ancient time until this present time. In these days along with the convenience of accessibility to synthetic medicine in various drugstore become one of threat for the existence of traditional herbal medicine. Even though from Indonesian historical view, traditional herbal medicine should be able to flourish in the society. Many of the fake and high price tag of synthetic medicine problem cases increasing the awareness of the society to the danger of synthetic medicine, thus drive their desire to return to the traditional herbal medicine. 
Traditional herbal medicine are the traditional medication that has very important role, it's need to be public understandment that herbal medicine has a big potential and promising in the development health rate of society (Arifin, 2010). One of area in Central Java as center of herbal medicine industry is in Nguter, Sukoharjo. In Nguter there's traditional market that become trade center for herbal medicine and herbal medicine comodity, largest in South -East Asian. Herbal medicine and the trader have big potentital for the development of the country.

Social capital is one of the four pilars of sustainable development (Raja, 2014: 97). Social capital believed to give big impact for society. Along the line with World Bank (Cahyono and Adhiatma, 2013: 131) said that social capital refers to institutinal dimension, established relations, norm which form social relations quality and quantity in the society, to preserve the society unity collectively. Social capital dimension grow within society that include values and norms and also social interaction patterns which set the life of the society.

As Adler and Kwon (2000) said that social capital is ilustration of internal attachment that colors the collective structure, give coherence and collective benefits form a social dynamic that occour in the society. Meanwhile, Coleman (1999) also emphasize that social capital dimension inherent within social relation sturcture and social networks in the society. Thus social capital makes various social obligations, trust circumstances, reformation way, set norms, also social sanctions within society. Fukuyama (1995) beg to differ, he said that collective norms and values as key reference to manage act, behaviour and attitude, automatically become social capital. Social capital is just collective norms and values that been raised by trust. Wherein trust is the base of honest attitude, kilter and cooperative behaviour that appear form the inside of a community.

Social capital dimension emphasize on society togetherness to achieve goals increasing their life quality, therefore society needs to develop values that should be followed by them such as, participatory, caring, giving-receiving, and trust attitude. Along that line Sarageldin and Dasgupta (1999) said, social capital dimension depict all the things that make unity in society to collectively reach common goals, also in the inside tied together by values and norms that grows and must be followed dutifully.

Cahyono and Adhitama (2013), they found that social cpaital can increased the tobacco leaf farmers productivity in Wonosono. Those social capital manifest in the form of sharing information in the socialization and elucidation. Ottoson and Klyver (2010) in their research about social impact based on entrepreneur show that both is reciprocal and create a productive collaboration, the higer human capital quality the higher also their social capital. As for Otniel Pontoh (2010), that social capital of fisherman community empowerment in the Gangga Dua Village, Minahasa Utara needs bonding social capital, where values and norms of economical aspect still strongly influence the social capital. Therefore this collided with social structure that formed in the economical life of fisherman community.

\section{METHODS}

This descriptive quantitative research using survey approach. Primary data collection through questionaire, the sampling technique is total sampling where the total population is lees than 100 so that sample is whole population. Respondent on this research are 75 herbal medicine traders in Nguter market. Path analysis being used as anaysis technique, the aim is to know the direct influence form variables that will be measured with SPSS 21 software as analysis tool. 


\section{Social Capital}

\section{LITERATURE REVIEW}

Coleman (1999), social capital is society ability to work together, to reach common goals, within various communities and organizations. Supriono (2008) and Cox, Partha and Ismail (1999) said that social capital is relations and norms that shape quality and quantity of social relationship in the society in the board spectrum, that is as social attachment that collectively keep the society united. Fukuyama (1995) said that social capital as a series of chains of internal values or norms that society have among their members in the community that allows cooperation happens among them. Burt (1991) defined social capital as society ability to do asociation with one and another and thus become a very important power, not only for economic life but also at every aspect of other social exsistence. Cox (1995) in Hasbullah (2006) said that social capital as a chains of relation process among human that supported by networks, norms and social trust that allows the efficiency and effectivity of coordination and collaboration to collective advantages and policies.

In the same path, Solow (1999) defined social capital as a chain of series of values and norms that manifest in the form of behaviour that able to support the capacity and capability to cooperative and coordination to achieve big contribution towards sustainable productivity. However Cohen and Prusak L. (2001) said that, social capital in each relations, tied together by trust, mutual understanding, shared values among the community memeber to make a possibility to perform collective act efficiently and effectively. In accordance with Cohen and Prusak, Hasbullah (2006) explain that social capital as everything that related to the cooperation in the sociery to achieve a better life quality. It's supported by values and norms, with base elemet such as trust, reciprocal conditions, collective rules in the society.

Trust become main element to form social capital in the rural community. Meanwhile other aspect such as cooperation, networks wont be formed well if it's not base on mutual trust among members of community. Power of cooperation and networks that formed in the society are operational development and mutual trust in the socio-culture, economic and government area. In the social life of rural community, trust should not be viewed only as a personality or intrapersonal problems, but it's also covers the extrapersonal ang intersubjective problems.

Trust is a result form intercation that include society in the group at level neighborhood, hamlet area and village, even the development of this social networks beyond village, and form a cross-village social network. In the neighborhood or hamlet community that contain a relatively high level of social contradiction, therefore the shape of trust is relatively narrow up until level of personal and brotherhood, in that community fueled by primordial values or ascriptive.

\section{RESULT AND DISCUSSION}

This research result as ilustrated in the table 1, that path coefficient from simultaneously test is significant, therefore we can draw conclusion to reject Ho and accept Ha, which means we able to proceed the test to individual level test. 
Table 1. Path Analysis Statistic Test Report

\begin{tabular}{|l|c|c|c|}
\hline \multicolumn{1}{|c|}{ Structural Equation } & $\begin{array}{c}\text { Path Coeff. } \\
\text { (beta) }\end{array}$ & Sig. & Conclusion \\
\hline $\mathrm{X} 1$ to Y & 0.378 & 0.001 & Ha Accepted \\
\hline $\mathrm{X} 2$ to Y & 0.347 & 0.002 & Ha Accepted \\
\hline $\begin{array}{l}\text { Coeffient of Determination } \\
\left(\mathrm{R}^{2}\right)\end{array}$ & \multicolumn{3}{|c}{0.414} \\
\hline
\end{tabular}

Source: Report of Primary Data Analysis, 2018

Note: *significant at $\alpha=0.05$

From individual test, it turns out that the path coefficient for variables X1, X2 towards Y statistically were significant, therefore Ho rejected and Ha accepted. Meanwhile the number for coefficient of determination $\mathrm{R}^{2}$ is 0,414 . This is means there's contribution as much as $41,4 \%$ from free variable to predict bound variable, meanwhile the rest of 58,6\% explained by any other variables outside the model. Furthermore, the analysis result in the table 1 . could to be translated in the path diargm as ilustrated in the Figure 1. bellow.

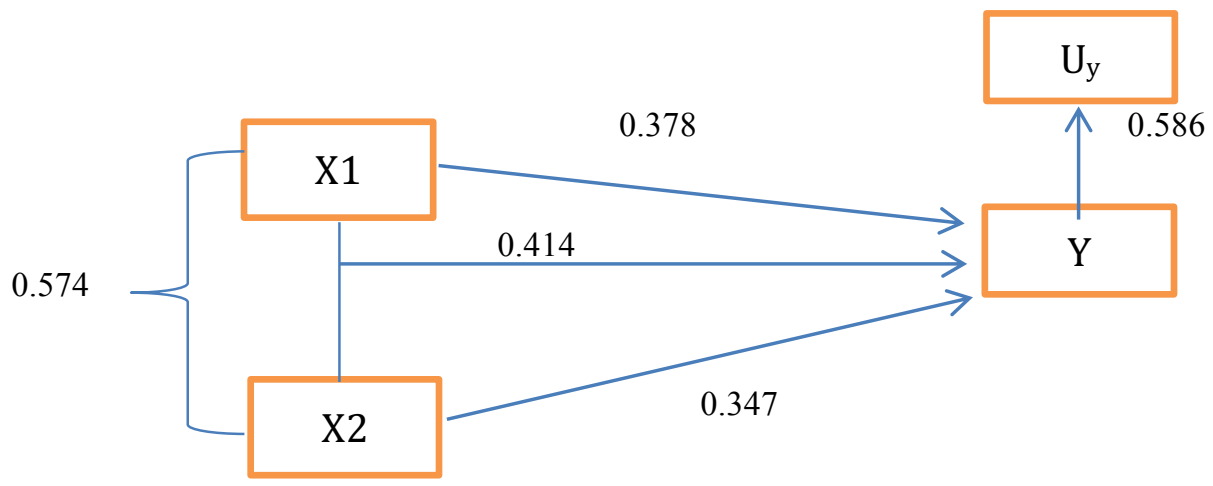

Fig 1. Structure of Relation between Variable X1, X2 and Variable Y.

\section{Direct Influence}

Form the figure 1. shows that trust variable has contribution towards sustainability of herbal medicine trade as much as 0.378 and significancy of .001 smaller than .05 significant level. This is means trust variable significantly influence towards sustainability of herbal medicine. Networks variable has contribution towards sustainability of herbal medicine trade as much as 0.347 and significant value of 0.002 smaller that .05 significant level. This is menas that network variable significantly influence towards sustainability of herbal medicine.

\section{Total Influence}

Form fig 1. shows that total influence of trust towards sustainability of herbal medicine trade has total contribution of 0.142 or as much as $14,2 \%$. Meanwhile total influence network variable sustainability of herbal medicine trade has contribution of 0.121 or as much $12.1 \%$

This research explain that trust influence the sustainability of herbal medicine trade.In accordance of Fukuyama (1995), trust is hope that grow within society in the forms of honest behaviour, kilter and cooperation that based on the collective norms. Along that line, Badaruddin (2006) research show the effort to built and flourish social capital is a process that needs time and commitment, especially in society that experienced trust cirsis, and the ability to bulid social capital in the community is one of the effort to empower those community, socially or economically.

Meanwhile herbal medicine reliance towards relatives, customers, fund managment agency, fellow trader and market administrator is very important the herbal medicine marketing. 
Reliance that entwined between herbal medicine traders formed form a very long time, because of they are comrade in arms. This reliance or trust has a big role in the sustainbility of herbal medicide trade related with the desire and needs to keep the reliance, with fellow traders, customers, market administrator and herbal medicine's fund managment agency

Ariana (2009) research report explained that money shows social capital economic value identified on the brotherhood relation among agro-industries actor, cooperation of procurement and supply raw materials, distribution and product marketing, bussines partner and information sharing abour bussiness management. This is goes well with this research found that networks has significant direct influence towards the sustainbility of herbal medicine trade of 0.347 or contribution as much as $12.1 \%$. This research is also in the line with Mudiarta (2009) that explained that networks formed form personal relationship, individualinstitutions and networks between institutions. Mudiarta said social stucture influenced by networks has economic benefit. In addtion, Putnam (Surharto 2007 orign. 1993) said that dynamic infrastructure form social capital manifest through cooperation networks among society. Those networks facilitate communication and interaction, allows trust flourish dan strenghten the cooperation. Healthy society tends to have a strong social networks. This is along the line with Verawati (2012), that networks expand the craft product marketing, raw materials for cfrater easier to get, increasing the good relations between crafter, between traders, or relations between crafter-traders, crafter easier to get order form customers In accordance with Fargestya (2017) that networks has role in the supply and procurement of raw materials, procurement of trade goods, capital supply and marketing of batik trade.

Well manage intercation will help to build welfare of society and one of manifestation of social capital. Syahyuti (2006), said that social capital is a strong baseline, which is it carried out well will relieve development fees. Furthermore Coleman (1990), show that networks in the social capital is a consequences if manifestation trust expanding and theres reciprocal relation within society, along society hope or desire. Based on that good interaction can be applied on the herbal medicine trade, therefore the higher herbal medicine trader interaction with customers, herbal medicine's fund management agency, between traders and market administrator the higher also income, welfare and sustainbility of herbal medicine.

\section{CONCLUSION}

Conclusion can be drawn that trust variable has big contribution as much as $14,2 \%$ that show the power of trust become the strengh of social capital between herbal medicine traders in sustainbility of herbal medicine trade.

\section{References}

Adler, P.S and Kwon. 2000. Social Capital: Prospects for a new concept. Academy of Management Review, 27 (1), pp. 17-40.

Ariana L dkk. 2009. Pengaruh Modal Sosial dalam Kemandirian Sentra Industri yang Berlokasi di Daerah Pedesaan. Lipi Press: Jakarta.

Arifin, Widayat. 2010. Keberlangsungan Industri Jamu Serbuk dan Faktor-Faktor Yang Mempengaruhi Di Kecamatan Nguter Kabupaten Sukoharjo.

Badaruddin. 2006. Pemanfaatan Modal Sosial Dalam Upaya Peningkatan Kesejahteraan Keluarga Pada Komunitas Petani Karet di Kec. Kao, Kab. Pasaman Sumatera Barat. Artikel Ilmiah Universitas Sumatra Barat.

Burt, R. 1991. Structural Holes; The Social Structure of Competition, Camabridge, Harvard University Press.

Cahyono, Budi dan Adhiatma. 2012. Peran Modal Sosial Dalam Peningkatan Kesejahteraan Masyarakat Petani Tembakau Di Kabupaten Wonosobo. Prceeding of Conference In Business, Accounting and Management (CBAM).

Cohen, S. Prusak L. 2001. In Good Company: How Socal Capital Makes Organization. 
Coleman, James. 1990. Foundation of Social Theory. Cambridge: Harvard University Press. 1999. Social Capital in the Creation of Human Capital. Cambridge Mass.

Fargestya, Ulfa. 2017. Pengaruh Tingkat Jaringan Sosial, Etos Kerja, Dan Strategi Berusaha Terhadap Kelangsungan Usaha Pedagang Batik Di Pasar Klewer Pasca Kebakaran Tahun 2014. Pasacasarjana UNS.

Fukuyama. 1995. Trust: The Social Virtues and The Creation of Prosperity. Free Press. ISBN 0-02-91-976_0

Hasbullah, Jousari. 2006. Social Capital (Menuju Keunggulan Budaya Manusia Indonesia). Jakarta: MR-United Press.

Mudiarta, K. G. 2009. Jaringan Sosial (Networks) dalam Pengembangan Sistem Usaha Agribisnis: Perspektif Teori dan Dinamika Studi Kapital Sosial. J. Agri Ekonomi. 27 (1): 1-12.

Partha, D and Ismail S. 1999. Social Capital A Multifaceted Perspective. Washington DC: The World Bank.

Purwaningsih, Ernie H. 2013. Jamu, Obat Tradisional Asli Indonesia Pasang Surut Pemanfaatannya di Indonesia. Departemen Farmasi Fakultas Kedokteran Universitas Indonesia: Jakarta.

Pontoh, Otniel. 2010. Identifikasi Dan Analisis Modal Sosial Dalam Rangka Pemberdayaan Masyarakat Nelayan Desa Gangga Dua Kabupaten Minahasa Utara. Jurnal Perikanan dan Kelautan Tropis. Vol-VI-3, Desember 2010.

Raja, Pawel. 2014. Social Capital and Sustainable Development in the Framework of New Institutional Economics. Pertanika J. Soc. Sci \& Hum. 22 (S): 97-110.

Serageldin, Ismail and Christian Grootaert. 1999. Definising social capital: An Integrating view in Dasgupta and Ismail Serageldin (eds), Social Capital A Multifaceted Perspective: Washington DC. World Bank.

Solow, R. M. 1999. Notes Social Capital and Economic Performance. In Partha D., Ismail S.,

Suharto. 2007. Modal Sosial dan Kebijakan Publik.

Supriono, Flassy and Rais. 2008. Modal Sosial: definisi, dimensi, dan tipologi.

Syahyuti. 2010. Pengembangan Modal Sosial Masyarakat Dalam Upaya Membangun Kelembagaan dan Pemberdayaan Petani Miskin. Badan Penelitian dan Pengembangan Pertanian. Departemen Pertanian. Hal 5-7

Verawati. 2012. Peran Modal Sosial Dalam Strategi Industri Kreatif (Studi DI Sentra Kerajinan Kayu Jati Desa Jepon, Kabupaten Blora Jawa Tengah). Jurnal Students, Volume III, Number 3 Tahun 2012. 